\title{
Placental infection with SARS-CoV-2, analysis of 16 cases and literature review
}

\author{
Salmeh Dadgar ${ }^{1} \cdot$ Malihe Mahmoudinia $^{2}\left(\right.$ Azam Akbari $^{3} \cdot$ Elaheh Zandieh $^{4} \cdot$ Armin Attaranzadeh $^{4}$. \\ Sajjad Hoseinpour ${ }^{5} \cdot$ Nafiseh Jahanpak $^{3} \cdot$ Ashraf Tavanaee Sani $^{1}$ - Seyed Ali Mohammadi ${ }^{1}$
}

Received: 10 June 2021 / Accepted: 15 December 2021 / Published online: 28 January 2022

(c) The Author(s), under exclusive licence to Springer-Verlag GmbH Germany, part of Springer Nature 2021

\begin{abstract}
Purpose Since December 2019, the whole world has been affected by coronavirus [severe acute respiratory syndrome coronavirus 2 (SARS-CoV-2)]. However, the effects of COVID-19 infection on pregnancy and fetal transmission are still unclear. Therefore, this study was conducted to evaluate placenta samples regarding detection of SARS-CoV-2 RNA in women affected with COVID-19.

Method This study was a part of a cohort study carried out on pregnant women with a diagnosis of COVID-19 infection who had been admitted to the Imam Reza Hospital in Mashhad, Iran, from March 20 to August 5, 2020. Clinical and laboratory information of all the patients was collected and chest computed tomography (CT) scans were reviewed. Totally, 16 placental tissue were prepared for real time polymerase chain reaction (RT-PCR) testing. All samples were tested by PowerChek PCR real-time kit (South Korea) with 2 target genes (E gene and Rd Rp gene), and Pishtaz Teb kit, (Iran) with 2 target genes (N gene and RdRp gene).

Result In the first RT-PCR kit by PowerChek kit, 6 samples were positive for a single gene (E gene) and 2 samples were positive for both genes (E gene and Rd Rp gene). In the second RT-PCR kit by Pishtaz Teb kit, 3 samples were positive for two genes ( $\mathrm{N}$ gene and RdRp gene).

Conclusion This present study showed that infection of placenta with SARS-CoV-2 may occur in pregnancy. However, whether this infection leads to neonatal infection and serious complication in pregnancy remains unclear.
\end{abstract}

Keywords Placenta $\cdot$ COVID-19 $\cdot$ Pregnancy $\cdot$ Vertical transmission

\section{Introduction}

Coronaviruses are important human and animal pathogens. At the end of 2019, a novel coronavirus was identified as the cause of a cluster of pneumonia cases in Wuhan, a city

Malihe Mahmoudinia

mahmoudiniam@mums.ac.ir

1 Faculty of Medicine, Mashhad University of Medical Sciences, Mashhad, Iran

2 Department of Obstetrics, Faculty of Medicines, Maternal and Neonatal Research Center, Mashhad University of Medical Sciences, Mashhad, Iran

3 Mashhad University of Medical Sciences, Mashhad, Iran

4 Imam Reza Hospital, Mashhad University of Medical Sciences, Mashhad, Iran

5 Department of Molecular Genetic, Medical Laboratory, Imam Hosein Hospital, Mashhad, Iran in Hubei Province in China. It was spread rapidly, resulting in an epidemic throughout China, followed by an increasing number of cases in other countries all over the world [1].

The body of evidence suggests that pregnancy does not increase the risk for acquiring COVID-19 infection but appears to worsen the clinical course of COVID-19 compared with nonpregnant females of the same age [2, 3].Risk factors for severe disease and death in pregnancy include older mean age ( $\geq 35$ years), obesity, and preexisting medical comorbidities (particularly hypertension and diabetes) [4].

Possible vertical transmission has been reported in several cases of peripartum maternal infection in the third trimester, suggesting that congenital infection is possible but uncommon (0/310 cases in one review study) [5, 6]. Neonatal outcomes have been uniformly good for at-risk neonates in the absence of other issues, such as preterm birth or an abruption [5]. 
In most women tested positive by PCR for SARS-CoV-2 in the nasopharynx, vaginal, and amniotic fluid samples have been negative by PCR testing to date [7-9] but, one patient with a positive vaginal swab has been reported [10].

Viremia rates appear to be low and transient in patients with COVID-19 (1 percent in one study) [11], suggesting that placental seeding and vertical transmission would not be common. Most placenta samples studied so far have had no evidence of infection, but the virus has been identified in a few cases [12].

In one study, Of 11 placental or membrane swabs sent for testing after delivery, 3 swabs returned with positive results for SARS-CoV-2, all in women with severe to critical COVID-19 at time of delivery. Placental swabs were obtained from the amniotic surface after clearing the surface of maternal blood (PCR of placental sample). Membrane swabs were obtained from between the amnion and chorion after manual separation of the membranes (PCR of membrane sample) [13].

Another report described two COVID-19 positive mothers in whom the samples obtained from fetal side (syncytiotrophoblast) of their placentas and neonates were also positive by PCR testing [14].

A few other possible cases of congenital infection based on newborn laboratory and/or clinical findings have been reported [15] but SARS-CoV-2 testing on fetal blood, amniotic fluid, and placenta in these cases was either negative or not performed. Although some had an elevated immunoglobulin M (IgM) level and/or pneumonia, positive IgM results are not definitive evidence of in utero infection (false positives and cross reactivity may occur), and in many of these cases, early infant infection may have been due to postnatal contact with the infected parents or caregivers [16]. Therefore, this study was done to investigate placenta samples of the patients with confirmed diagnosis of COVID19 regarding detection of SARS-CoV-2 RNA.

\section{Methods}

This study was a part of a cohort study carried out on pregnant women with a diagnosed with COVID-19 infection who had been admitted to the Imam Reza Hospital in Mashhad, Iran, from March 20 to August 5, 2020. Diagnosis of COVID-19 pneumonia was based on real-time reverse transcription-polymerase chain reaction (RT-PCR) test that was done on throat swab samples or through involvement of lung in high-resolution computed tomography (HRCT) finding.

All the subjects were informed about the objective and procedure of the study and an informed written consent was obtained from all of them regarding their enrollment in the study. The ethics committee of Mashhad University of
Medical Sciences approved the study with the approval code of IR.MUMS.REC.1399.214.

All vital signs of patients with COVID-19 symptoms including pulse rate (PR), respiratory rate (RR), blood pressure (BP), body temperature (T), and $\mathrm{O} 2$ saturation were monitored during hospitalization. Laboratory tests such as complete blood count differential(CBC diff), liver function test(LFT), blood urea nitrogen(BUN), creatinine $(\mathrm{Cr})$, C-reactive protein(CRP), erythrocyte sedimentation rate(ESR), BG, and $\mathrm{RH}$ were investigated at the time of admission and then, they were repeated depending on clinical symptoms and the patient's condition. Every day the patients were visited by the gynecologist and infectious disease specialist at the hospital. Patients with severe dyspnea, respiratory rate $>30$ per minute and blood oxygen saturation $\leq 93 \%$ on room air, were controlled in the intensive care unit (ICU).

Termination of pregnancy was performed according to obstetrical indication. All the people associated with childbirth, physicians, midwives and pediatricians were equipped with complete protective equipment, including clothing and an N95 mask. The patients also used the N95 mask during labor.

The babies were dried immediately after birth. Umbilical cord was quickly clamped and the babies were transferred to an isolation suite of neonatal intensive care unit (NICU) without having any contact with the mother. At the beginning of the coronavirus pandemic, our policy in our center was to separate the fetus from the mother because the rate of transmission of the virus to the mother was unknown. The placenta tissue was collected under sterile condition and tissue samples were taken from fetal side near the umbilical cord insertion. $1 \mathrm{~cm}^{3}$ from the placenta fetal face was taken in a sterile dry tube immediately after delivery and was kept at - 70 freezer until performing laboratory studies. Placentas were obtained from Normal Vaginal Delivery (NVD) or Cesarean Section (CS) as Table 3.

Placenta samples were extracted from the ROJEH Company (Iran) using an RNA extraction kit with positive and negative control to confirm extraction procedures.

Totally, 16 samples were tested by PowerChek polymerase chain reaction (PCR) real-time kit (South Korea) with 2 target genes (E gene and RdRp gene), and Pishtaz Teb kit (Iran) with 2 target genes ( $\mathrm{N}$ gene and RdRp gene) as negative and positive controls. Positive samples had risen as cycle 22-32. In addition, all the samples underwent standardized histopathological examination.

\section{Data collection}

We collected demographic data, clinical symptoms, laboratory tests, treatment, delivery method, and maternal outcome from their electronic medical record of the mother. All the 
information about neonatal outcomes including, gestational age at the time of delivery, birth weight, Apgar score, stillbirth was also reviewed. In addition, if necessary, the patient was called in all cases and accuracy of the information was checked. Data were confirmed by a co-investigator.

\section{Results}

Totally, 16 patients were diagnosed with COVID-19 among whom 15 patients had positive PCR testing, and one patient had severe symptoms with positive findings on HRCT of the chest that was leading to her death. Mean age of women was between 18 and 42 years old, and age of pregnancy was between 22 and 41 weeks. Four women had a history of contact with the affected people in the family. Three patients had diabetes and two other patients had hypertension (HTN) during the pregnancy. Mean time of onset of delivery symptoms was 1-15 days and medium length of admission in hospital was between 2 and 17 days. Eight patients presented with fever, cough, and dyspnea, one person only had fever and the rest of them did not have fever. Four patients reported anosmia. Some patients reported other symptoms, such as sore throat, chills, nausea, and muscle aches.

Twelve patients did not have any problems after being diagnosed with COVID-19 during and after pregnancy (Table 1). One case had a premature rupture of the membrane (PROM) and one case had a postpartum hemorrhage. Among16 patients, 3 of them had a severe type of disease admitted in ICU and unfortunately, death was reported in 2 cases.

The results of laboratory tests showed that 8 out of 16 pregnant women with COVID-19 pneumonia had lymphopenia $\left(<1.0 \times 10^{9}\right.$ cells per $\left.\mathrm{L}\right)$. Results of all the liver tests were in normal range in the patients. Thirteen patients had the elevated concentrations of CRP ( $>10 \mathrm{mg} / \mathrm{L})$. CRP test was not performed on 3 patients. Result of PCR test was positive in 15 patients but it was negative in one patient as she had positive findings in HRCT. A chest CT scan was performed for 10 patients. Eight patients showed typical findings of chest CT images, but 2 patients had no pulmonary involvement in CT scan and HRCT was not performed for the rest of the patients due to unwillingness of the mother (Table 2).

Out of 16 patients, 5 infants were born preterm. Intrauterine fetal demise (IUFD) occurred in one case, which was a twin pregnancy at 23 weeks (Table 3). Two of the neonates had a birthweight lower than $2500 \mathrm{~g}$. Twelve live births had a 1-min Apgar score of 8-9 and a 5 min Apgar score of 9-10, and 3 neonates had a lower Apgar score. None of these neonates showed any signs and symptoms of COVID19 (Table 3).

Ten newborns (including twins) underwent throat swab test for COVID-19 after birth. Eight cases were negative but test was positive in 2 neonates (Table 4). The presence of SARS-CoV-2 was tested in the placenta of all deliveries. In the first RT-PCR kit by PowerChek kit, 6 samples were positive for a single gene, 2 samples were positive for both genes. In the second RT-PCR kit by Pishtaz Teb kit, 3 samples were positive for two genes (Table 5). Samples of the placenta were also positive in two patients who died.

In the pathological examination, there was no infiltration of acute inflammation in the membranes and in half samples, scattered focal ischemic necrosis was observed in $2-5 \%$ villous placenta.

\section{Discussion}

This study showed that out of 16 patients diagnosed with COVID-19, placenta samples were positive in 8 patients, of which 6 patients were positive in a single gene and 2 patients were positive in 2 genes. Death was reported in 2 cases, both of which had placental involvement. In addition, in 2 cases, neonatal throat swab samples tested positive for SARS-CoV-2.

The risk of vertical transmission in pregnant women with COVID-19 has been very controversial in the literature. Placenta acts as a physical barrier between mother and fetus, and it is defined as the first line of defense, to prevent transmission of infectious agents from mother to fetus during pregnancy. Nevertheless, some infectious agents, such as Toxoplasma, rubella, cytomegalovirus, herpes, and Zika can pass through placental barrier leading to activation innate immune response and causing fetal and mother complications [17]. Therefore, there is an increasing concern about congenital infection and adverse pregnancy outcome in pregnant women with COVID-19. Diagnosis of intrauterine infection is based on detection of the virus in cord blood, amniotic fluid, or placenta [9].

So far, there has been little agreement on vertical transmission of SARS-CoV-2 in pregnancy $[6,18]$. One mechanism for intrauterine infection is high expression of cell membrane angiotensin converting enzyme II (ACE2) as a receptor of SARS-CoV-2 in placental syncytiotrophoblast, and cytotrophoblasts. Also, spike protein of the virus is motivated by an enzyme called as transmembrane serine protease 2 (TMPRSS2) gene. It is assumed that the virus binds to this receptor to enter the cell [19-22].

Although, several studies have investigated the risk of vertical transmission with different methods, most of these studies have been limited to small number of cases. Preliminary studies have failed to detect the virus in the placenta and they have concluded vertical transmission of the virus during pregnancy is unusual [23-27]. 
Table 1 Clinical characteristics of patients

\begin{tabular}{|c|c|c|c|c|c|c|c|c|c|}
\hline & $\begin{array}{l}\text { Date of } \\
\text { admission }\end{array}$ & Age (years) & $\begin{array}{l}\text { Gestational } \\
\text { age on } \\
\text { admission }\end{array}$ & $\begin{array}{l}\text { Other family } \\
\text { members } \\
\text { affected }\end{array}$ & $\begin{array}{l}\text { First } \\
\text { symptom(s) }\end{array}$ & $\begin{array}{l}\text { Medical his- } \\
\text { tories during } \\
\text { pregnancy }\end{array}$ & $\begin{array}{l}\text { Onset } \\
\text { symptom } \\
\text { to delivery } \\
\text { (day) }\end{array}$ & $\begin{array}{l}\text { Complica- } \\
\text { tions }\end{array}$ & $\begin{array}{l}\text { Duration of } \\
\text { hospitalization } \\
\text { (day) }\end{array}$ \\
\hline Patient 1 & $8 \mathrm{Aug}$ & 22 & 40.6 & Negative & $\begin{array}{l}\text { Fever, } \\
\text { cough, } \\
\text { dyspnea }\end{array}$ & $\begin{array}{l}\text { HTN, Preec- } \\
\text { lampsia }\end{array}$ & 1 & Negative & 4 \\
\hline Patient 2 & $25 \mathrm{Apr}$ & 21 & 39 & Negative & $\begin{array}{l}\text { Cough, } \\
\text { Anosmia }\end{array}$ & Negative & 1 & Negative & 8 \\
\hline Patient 3 & 12 May & 25 & 41.1 & Negative & Fever & Negative & 1 & Negative & 4 \\
\hline Patient 4 & 3 June & 21 & 35 & Positive & Anosmia & Diabetic & 4 & $\begin{array}{l}\text { Post-partum } \\
\text { hemor- } \\
\text { rhage }\end{array}$ & 7 \\
\hline Patient 5 & 7 June & 23 & 36 & Positive & $\begin{array}{c}\text { Anosmia, } \\
\text { dyspnea, } \\
\text { myalgia }\end{array}$ & Diabetic & 4 & Negative & 8 \\
\hline Patient 6 & 12 June & 18 & 38 & Negative & $\begin{array}{l}\text { Fever, dysp- } \\
\text { nea, cough }\end{array}$ & Negative & 2 & Negative & 7 \\
\hline Patient 7 & 21 June & 35 & 32.3 & Negative & Anosmia & Negative & 15 & PROM & 10 \\
\hline Patient 8 & 19 July & 29 & 37 & Negative & $\begin{array}{l}\text { Fever, chill, } \\
\text { dyspnea }\end{array}$ & Negative & 11 & Negative & 17 \\
\hline Patient 9 & 17 July & 29 & 37 & Negative & $\begin{array}{l}\text { cough, } \\
\text { dyspnea, } \\
\text { myalgia }\end{array}$ & Negative & 2 & Negative & 3 \\
\hline Patient 10 & 15 July & 42 & 37 & Negative & $\begin{array}{l}\text { Fever, } \\
\text { cough, } \\
\text { dyspnea, } \\
\text { myalgia }\end{array}$ & Negative & 7 & Negative & 10 \\
\hline Patient 11 & 29 July & 42 & 38 & Positive & $\begin{array}{l}\text { Fever, } \\
\text { cough, } \\
\text { dyspnea, } \\
\text { myalgia, } \\
\text { sore throat, } \\
\text { headache, } \\
\text { chill }\end{array}$ & Negative & 12 & Negative & 4 \\
\hline Patient 12 & 28 July & 34 & 41 & Negative & $\begin{array}{l}\text { cough, } \\
\text { dyspnea, } \\
\text { sore throat, } \\
\text { headache, } \\
\text { chill }\end{array}$ & Negative & 2 & Negative & 6 \\
\hline Patient 13 & 24 July & 26 & 41 & Negative & $\begin{array}{l}\text { myalgia, } \\
\text { cough }\end{array}$ & Negative & 9 & Negative & 2 \\
\hline Patient 14 & 21 July & 25 & 34.6 & Positive & $\begin{array}{l}\text { cough, } \\
\text { dyspnea, } \\
\text { sore throat, } \\
\text { headache, } \\
\text { chill, vom- } \\
\text { iting }\end{array}$ & Negative & 9 & Negative & 6 \\
\hline Patient 15 & 28 May & 31 & 22.5 & Negative & $\begin{array}{l}\text { Fever, } \\
\text { cough, } \\
\text { dyspnea }\end{array}$ & HTN & 7 & $\begin{array}{l}\text { Admission } \\
\text { in ICU, } \\
\text { mechanical } \\
\text { ventilation, } \\
\text { Severe } \\
\text { preeclamp- } \\
\text { sia, Acute } \\
\text { Tubular } \\
\text { Necrosis } \\
\text { (ATN), } \\
\text { death }\end{array}$ & 8 \\
\hline
\end{tabular}


Table 1 (continued)

\begin{tabular}{|c|c|c|c|c|c|c|c|c|c|}
\hline & $\begin{array}{l}\text { Date of } \\
\text { admission }\end{array}$ & Age (years) & $\begin{array}{l}\text { Gestational } \\
\text { age on } \\
\text { admission }\end{array}$ & $\begin{array}{l}\text { Other family } \\
\text { members } \\
\text { affected }\end{array}$ & $\begin{array}{l}\text { First } \\
\text { symptom(s) }\end{array}$ & $\begin{array}{l}\text { Medical his- } \\
\text { tories during } \\
\text { pregnancy }\end{array}$ & $\begin{array}{l}\text { Onset } \\
\text { symptom } \\
\text { to delivery } \\
\text { (day) }\end{array}$ & $\begin{array}{l}\text { Complica- } \\
\text { tions }\end{array}$ & $\begin{array}{l}\text { Duration of } \\
\text { hospitalization } \\
\text { (day) }\end{array}$ \\
\hline Patient 16 & 30 July & 33 & 33 & Negative & $\begin{array}{l}\text { Fever, } \\
\text { cough, } \\
\text { dyspnea, } \\
\text { myalgia, } \\
\text { sore throat, } \\
\text { headache, } \\
\text { chill }\end{array}$ & GDM & 1 & $\begin{array}{l}\text { Admission } \\
\text { in ICU, } \\
\text { preec- } \\
\text { lampsia, } \\
\text { mechanical } \\
\text { ventilation, } \\
\text { death }\end{array}$ & 4 \\
\hline
\end{tabular}

Table 2 Laboratory and imaging characteristics

\begin{tabular}{|c|c|c|c|c|c|c|c|c|c|}
\hline $\begin{array}{l}\text { Laboratory and } \\
\text { imaging character- } \\
\text { istics }\end{array}$ & $\begin{array}{l}\text { White } \\
\text { blood cell } \\
\text { count } \\
\left(\times 10^{9} \text { cells }\right. \\
\text { per } \mathrm{L})\end{array}$ & $\mathrm{HB}$ & PLT & $\begin{array}{l}\text { Lymphocyte count } \\
\left(\times 10^{9} \text { cells per } \mathrm{L}\right)\end{array}$ & $\operatorname{ALT}(\mathrm{U} / \mathrm{L})$ & AST (U/L) & $\begin{array}{l}\text { C-reactive pro- } \\
\text { tein concentra- } \\
\text { tion } \\
(\mathrm{mg} / \mathrm{L})\end{array}$ & $\begin{array}{l}\text { SARS-CoV-2 } \\
\text { RT-PCR }\end{array}$ & $\mathrm{CT}$ \\
\hline Patient 1 & 10,600 & 13.9 & 146,000 & 23.5 & 11 & 21 & 90.3 & Positive & Positive \\
\hline Patient 2 & 10.2 & 12.6 & 238,000 & 12.7 & 16 & 20 & 55 & Positive & Positive \\
\hline Patient 3 & 22.8 & 11.6 & 160,000 & 5 & 5 & 11 & 25 & Positive & Positive \\
\hline Patient 4 & 2.3 & 11.2 & 215,000 & 23.7 & 53 & 33 & - & Positive & - \\
\hline Patient 5 & 5.5 & 10.7 & 99,000 & 27.3 & 11 & 15 & - & Positive & - \\
\hline Patient 6 & 4.6 & 10.9 & 69,000 & 13.7 & 7 & 14 & - & Positive & - \\
\hline Patient 7 & 9.2 & 12.5 & 182,000 & 17 & 22 & 22 & 13.2 & Positive & Negative \\
\hline Patient 8 & 5.6 & 11 & 172,000 & 16.4 & 6 & 10 & 144.5 & Positive & Negative \\
\hline Patient 9 & 8.9 & 11.3 & 175,000 & $15 / 2$ & 12 & 15 & $61 / 3$ & Positive & - \\
\hline Patient 10 & 11 & 14,1 & 180,000 & 12.1 & 13 & 25 & 92.8 & Positive & Positive \\
\hline Patient 11 & 10.9 & 10.7 & 217,000 & 7.1 & 8 & 16 & 34.5 & Positive & Positive \\
\hline Patient 12 & 9.2 & 11.7 & 209,000 & 17.9 & 13 & 28 & 77.2 & Positive & Negative \\
\hline Patient 13 & 10 & 12.1 & 170,000 & 23.9 & 7 & 14 & 74.3 & Positive & Negative \\
\hline Patient 14 & 16.6 & 10.9 & 225,000 & 9.8 & 18 & 22 & 87.9 & Positive & - \\
\hline Patient 15 & 11.1 & 9.2 & 242,000 & 10.4 & 12 & 18 & 107 & Negative & Positive \\
\hline Patient 16 & 7.2 & 11.5 & 235,000 & 10.3 & 17 & 30 & 145.2 & Positive & - \\
\hline
\end{tabular}

However, there are some reports of about detection of SARS-CoV-2 RNA in various fetal samples including the placenta [10, 13, 28-33].

In a case series study conducted by Penfield, 32 patients with COVID-19 were admitted, among whom membrane or placenta swabs were tested in 11 cases. Three out of 11 swabs were positive for SARS-CoV-2, nevertheless, the neonatal tests were negative for COVID-19 infection by RTPCR analysis [13]. In our study, in 2 cases with mild symptom in the mother. The neonates' tests were positive but had no symptoms and sign of COVID-19. In another case series study conducted by Patanè et al., 2 infants with COVID19 PCR positive test were reported from others diagnosed with COVID-19. SARS-CoV-2 RNA was detected on fetal side of the placenta as well as neonates tests. Also, in this study, contrary to our research, immunohistochemistry was performed that showed chronic intervillositis with CD68p macrophage infiltration. Similar to other studies, despite the positive test, the infants had no symptoms. The first infant and the second one were discharged from hospital after 10 and 20 days, respectively [14].

In contrast to the above-mentioned studies, Richtmann described 5 cases of IUFD in women with confirmed diagnosis of COVID-19 without a history of obstetric disorders. They found SARS-CoV-2 in one amniotic fluid and 2 placental swab samples. Acute chorioamnionitis was reported in histological assessment of placenta of all the cases. They proposed that SARS-CoV-2 infection in pregnancy can be associated with adverse neonatal outcomes, such as fetal death [34]. In our study, only one case of IUFD was observed in a woman with severe type of disease who was 
Table 3 Outcome of pregnancy

\begin{tabular}{|c|c|c|c|c|c|c|c|c|c|}
\hline & \multicolumn{5}{|l|}{ Treatment } & \multirow{2}{*}{$\begin{array}{l}\text { Admis- } \\
\text { sion in } \\
\text { ICU }\end{array}$} & \multicolumn{2}{|l|}{ Delivery } & \multirow{2}{*}{$\begin{array}{l}\text { Neonates } \\
\text { outcome }\end{array}$} \\
\hline & $\begin{array}{l}\text { Oxygen sup- } \\
\text { port (nasal } \\
\text { cannula) }\end{array}$ & $\begin{array}{l}\text { Antibiotic } \\
\text { therapy }\end{array}$ & $\begin{array}{l}\text { Antiviral } \\
\text { therapy }\end{array}$ & Colchicine & $\begin{array}{l}\text { Corticoid } \\
\text { therapy }\end{array}$ & & Method & $\begin{array}{l}\text { Indication for } \\
\text { C-section }\end{array}$ & \\
\hline Patient 1 & Positive & Positive & Negative & Negative & Negative & NO & $\mathrm{CS}$ & Preeclampsia & Term \\
\hline Patient 2 & Negative & Positive & Positive & Positive & Negative & NO & NVD & - & Term \\
\hline Patient 3 & Negative & Positive & Negative & Negative & Negative & NO & $\mathrm{CS}$ & Fetal distress & Term \\
\hline Patient 4 & Negative & Positive & Negative & Positive & Negative & NO & NVD & - & Preterm \\
\hline Patient 5 & Negative & Positive & Negative & Positive & Negative & NO & $\mathrm{CS}$ & Fetal distress & Preterm \\
\hline Patient 6 & Negative & Positive & Negative & Negative & Negative & NO & CS & Fetal distress & Term \\
\hline Patient 7 & Negative & Positive & Negative & Negative & Negative & NO & $\mathrm{CS}$ & $\begin{array}{l}\text { History of } \\
\text { C-section }\end{array}$ & Preterm \\
\hline Patient 8 & Positive & Positive & Positive & Positive & Negative & YES & $\mathrm{CS}$ & Fetal distress & Term \\
\hline Patient 9 & Negative & Positive & Negative & Negative & Negative & NO & $\mathrm{CS}$ & $\begin{array}{l}\text { History of } \\
\text { C-section }\end{array}$ & Term \\
\hline Patient 10 & Negative & Positive & Negative & Negative & Negative & NO & CS & $\begin{array}{l}\text { History of } \\
\text { C-section }\end{array}$ & Term \\
\hline Patient 11 & Negative & Positive & Negative & Negative & Negative & NO & NVD & - & Term \\
\hline Patient 12 & Negative & Positive & Negative & Negative & Negative & NO & $\mathrm{CS}$ & $\begin{array}{l}\text { Lack of } \\
\text { progress in } \\
\text { labor }\end{array}$ & Term \\
\hline Patient 13 & Negative & Positive & Negative & Negative & Negative & NO & NVD & - & Term \\
\hline Patient 14 & Negative & Positive & Negative & Negative & Positive & NO & CS & Twin & Preterm \\
\hline Patient 15 & Positive & Positive & Positive & Negative & Positive & YES & NVD & - & IUFD \\
\hline Patient 16 & Positive & Positive & Positive & Remdesivir & Positive & YES & CS & Breech & Preterm \\
\hline
\end{tabular}

Table 4 Outcome of neonatal

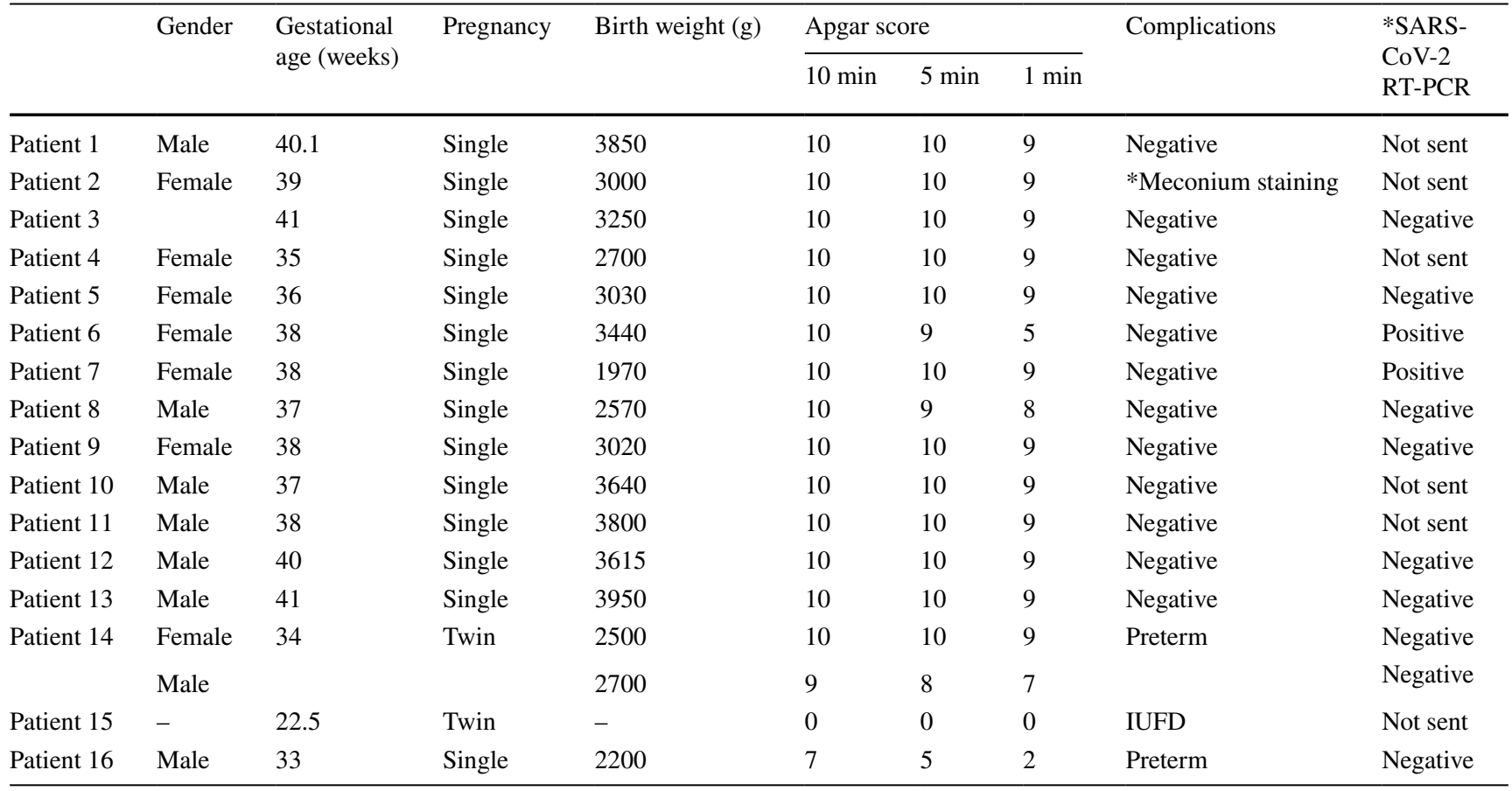

*SARS-CoV-2 RT-PCR: Neonate nasopharyngeal swab samples for SARS-CoV-2

*Meconium Staining: Meconium stained Amniotic fluid 
Table 5 SARS-CoV-2 RT-PCR of placenta

\begin{tabular}{lll}
\hline & PowerChek & Pishtaz Teb \\
\hline Patient 1 & E positive & Negative \\
Patient 2 & Negative & Negative \\
Patient 3 & Negative & Negative \\
Patient 4 & Negative & Negative \\
Patient 5 & Negative & Negative \\
Patient 6 & RdRp/E positive & RdRp/N Positive \\
Patient 7 & E Positive & RdRp/N Positive \\
Patient 8 & Negative & Negative \\
Patient 9 & E Positive & Negative \\
Patient 10 & E Positive & Negative \\
Patient 11 & E Positive & Negative \\
Patient 12 & Negative & Negative \\
Patient 13 & Negative & Negative \\
Patient 14 & Negative & Negative \\
Patient 15 & E Positive & Negative \\
Patient 16 & RdRp/E Positive & RdRp/N Positive \\
\hline
\end{tabular}

a case with twin pregnancy at 22 weeks and died after one week of hospitalization in the ICU.

Results of a recent review study by Yin Ping Wong et al., showed that 9 studies had identified the SARS-CoV-2 viral RNA by RT-PCR test in the placenta, and totally 10 placenta samples were investigated in these studies. Only 2 neonate nasopharyngeal swab samples were positive for SARS-CoV-2, which is in line with our results indicating that although in 8 out of 16 cases, SARS-CoV-2 RNA was passed to the fetus, none of the infants had any signs and symptom of the virus [35]. Thus, the question is how the vertical transmission to fetus is very rare despite positive test result in the placenta sample.

Pique-Regi et al., in a study explained that transcription of ACE2 receptor and TMPRSS2 was extremely low for SARS-CoV-2 in the placenta, whereas receptor is highly expressed for other viruses resulting in pregnancy complication, such as Zika or cytomegalovirus, thus due to these differences in the level of activity of genes in the placenta, perinatal transmission of SARS-CoV-2 is very unusual [36].

Moreover, some studies have also proposed that rate of preterm delivery is increased in the patients with COVID-19 compared to the general population [37-39]. In our study, 6 out of 17 patients developed preterm labor and in 3 of them, the placenta samples were positive for SARS-CoV-2.

A strong point of our case series was that the number of the studied patients was much higher than the mentioned previous studies and also, result of testing was confirmed by two experienced people.

Two kits from two manufacturers were used to improve the quality of tests. The purpose was not to compare the two kits and use multiple genetic targets has been to identify the virus.

Nevertheless, this study had several limitations; first, tests were not performed for COVID-19 infection in all fetal samples, such as umbilical cord blood and amniotic fluid. Also, vaginal swab testing was not done in a sense of contamination for vaginally delivered placenta. Nasopharyngeal swab test did not perform for detection of SRAS-CoV-2 in all the neonates. Second, it is recommended to perform in-situ hybridization to directly visualize SARS-CoV-2 spike proteins in the syncytiotrophoblast samples as the molecular target since it retains the tissue morphology while it may be lost in other methods like PCR test. Finally, we could not rule out other reason for IUFD in one case.

In conclusion, results of the present study revealed that infection of placenta with SARS-CoV-2 may occur in pregnancy. However, whether this infection leads to neonatal infection and serious complication in pregnancy remains unclear. Thus, further studies with multiple testing methods for detection of SARS-CoV-2 are needed to confirm vertical transmission of COVID-19 to the neonates.

Acknowledgements We would like to thank the Clinical Research Development Unit, Imam Reza Hospital, Mashhad University of Medical Sciences, for their kind support.

Author contributions MM, NJ, AA, EZ: data collection. AA, SH: performing lab tests. MM, SD: writing the manuscript with support from ATS. MM, AA, SAM: design and implementation of the research, to the analysis of the results and to the writing of the manuscript.

Funding Mashhad University of Medical Science.

Data availability The datasets generated for this study are available on request to the corresponding author.

\section{Declarations}

Conflict of interest There are no conflicts of interest. All authors have consented to the publication of the paper "Placental Infection with SARS-CoV-2, Analysis of 16 case and literature review" in Archives of Gynecology and Obstetrics.

Informed consent All subjects were informed and consented to their enrollment. The ethics committee of Mashhad University of Medical Sciences approved the study with the approval code of IR.MUMS. REC.1399.214.

Consent for publication Not applicable.

\section{References}

1. World Health Organization (2021) Malnutrition factsheetGoogle Scholar, (n.d.). https://scholar.google.com/scholar?hl= en\&as_sdt $=0 \% 2 \mathrm{C} 5 \& \mathrm{q}=1 . \% 09$ World + Health+Organization.+ Director-General $\% 27 \mathrm{~s}+$ remarks+at+the+media+briefing+on+ 
2019-nCoV+on+11+February+2020.+https\%3A\%2F\%2Fwww. who.int $\% 2 \mathrm{Fdg} \% 2 \mathrm{Fspeeches} \% 2 \mathrm{Fdetail} \% 2 \mathrm{Fwho}$-director-general-sremark (Accessed 16 April 2021)

2. Zambrano LD, Ellington S, Strid P, Galang RR, Oduyebo T, Tong VT, Woodworth KR, Nahabedian JF III, Azziz-Baumgartner E, Gilboa SM, Meaney-Delman D (2020) Update: characteristics of symptomatic women of reproductive age with laboratory-confirmed SARS-CoV-2 infection by pregnancy status-United States, January 22-October 3, 2020. Morb Mortal Wkly Rep 69(44):1641

3. Allotey J, Stallings E, Bonet M, Yap M, Chatterjee S, Kew T, Debenham L, Llavall AC, Dixit A, Zhou D, Balaji R (2020) Clinical manifestations, risk factors, and maternal and perinatal outcomes of coronavirus disease 2019 in pregnancy: living systematic review and meta-analysis. BMJ 1:370

4. Karimi L, Makvandi S, Vahedian-Azimi A, Sathyapalan T, Sahebkar A (2021) Effect of COVID-19 on mortality of pregnant and postpartum women: a systematic review and metaanalysis. J Pregnancy 5:2021

5. Huntley BJF, Huntley ES, Di Mascio D, Chen T, Berghella V, Chauhan SP (2020) Rates of maternal and perinatal mortality and vertical transmission in pregnancies complicated by severe acute respiratory syndrome coronavirus 2 (SARS-Co-V-2) infection: a systematic review. Obstet Gynecol 136:303-312. https:// doi.org/10.1097/AOG.0000000000004010

6. Egloff C, Vauloup-Fellous C, Picone O, Mandelbrot L, Roques P (2020) Evidence and possible mechanisms of rare maternal-fetal transmission of SARS-CoV-2. J Clin Virol. https://doi.org/10. 1016/j.jcv.2020.104447

7. Yan J, Guo J, Fan C, Juan J, Yu X, Li J, Feng L, Li C, Chen H, Qiao Y, Lei D, Wang C, Xiong G, Xiao F, He W, Pang Q, Hu X, Wang S, Chen D, Zhang Y, Poon LC, Yang H (2020) Coronavirus disease 2019 in pregnant women: a report based on 116 cases. Am J Obstet Gynecol 223(111):e1-111.e14. https://doi. org/10.1016/j.ajog.2020.04.014

8. Qiu L, Liu X, Xiao M, Xie J, Cao W, Liu Z, Morse A, Xie Y, Li $\mathrm{T}$, Zhu L (2020) SARS-CoV-2 is not detectable in the vaginal fluid of women with severe COVID-19 infection. Clin Infect Dis 71:813-817. https://doi.org/10.1093/cid/ciaa375

9. Li P, Xie M, Zhang W (2020) Clinical characteristics and intrauterine vertical transmission potential of coronavirus disease 2019 infection in 9 pregnant women: a retrospective review of medical records. Am J Obstet Gynecol 223:955-956. https:// doi.org/10.1016/j.ajog.2020.08.059

10. Kirtsman M, Diambomba Y, Poutanen SM, Malinowski AK, Vlachodimitropoulou E, Parks WT, Erdman L, Morris SK, Shah PS (2020) Probable congenital sars-cov-2 infection in a neonate born to a woman with active sars-cov-2 infection. CMAJ 192:E647-E650. https://doi.org/10.1503/cmaj.200821

11. Wang W, Xu Y, Gao R, Lu R, Han K, Wu G, Tan W (2020) Detection of SARS-CoV-2 in different types of clinical specimens. JAMA-J Am Med Assoc 323:1843-1844. https://doi.org/ 10.1001/jama.2020.3786

12. Baud D, Greub G, Favre G, Gengler C, Jaton K, Dubruc E, Pomar L (2020) Second-trimester miscarriage in a pregnant woman with SARS-CoV-2 infection. JAMA-J Am Med Assoc 323:2198-2200. https://doi.org/10.1001/jama.2020.7233

13. Penfield CA, Brubaker SG, Limaye MA, Lighter J, Ratner AJ, Thomas KM, Meyer JA, Roman AS (2020) Detection of severe acute respiratory syndrome coronavirus 2 in placental and fetal membrane samples. Am J Obstet Gynecol MFM 2:100133. https://doi.org/10.1016/j.ajogmf.2020.100133

14. Patanè L, Morotti D, Giunta MR, Sigismondi C, Piccoli MG, Frigerio L, Mangili G, Arosio M, Cornolti G (2020) Vertical transmission of COVID-19: SARS-CoV-2 RNA on the fetal side of the placenta in pregnancies with COVID-19 positive mothers and neonates at birth. Am J Obstet Gynecol MFM. https://doi. org/10.1016/j.ajogmf.2020.100145

15. Khan S, Jun L, Nawsherwan R, Siddique Y, Li G, Han M, Xue G, Nabi JL (2020) Association of COVID-19 with pregnancy outcomes in health-care workers and general women. Clin Microbiol Infect 26:788-790. https://doi.org/10.1016/j.cmi. 2020.03.034

16. Kimberlin DW, Stagno S (2020) Can SARS-CoV-2 infection be acquired in utero?: more definitive evidence is needed. JAMA-J Am Med Assoc 323:1788-1789. https://doi.org/10.1001/jama. 2020.4868

17. Hoo R, Nakimuli A, Vento-Tormo R (2020) Innate immune mechanisms to protect against infection at the human decidual-placental interface. Front Immunol. https://doi.org/10.3389/fimmu.2020. 02070

18. Lamouroux A, Attie-Bitach T, Martinovic J, Leruez-Ville M, Ville Y (2020) Evidence for and against vertical transmission for severe acute respiratory syndrome coronavirus 2. Am J Obstet Gynecol 223(91):e1-91.e4. https://doi.org/10.1016/j.ajog.2020.04.039

19. Ashary N, Bhide A, Chakraborty P, Colaco S, Mishra A, Chhabria K, Jolly MK, Modi D (2020) Single-cell RNA-seq identifies cell subsets in human placenta that highly expresses factors driving pathogenesis of SARS-CoV-2. Front Cell Dev Biol. https://doi. org/10.3389/fcell.2020.00783

20. E Bloise, J Zhang, J Nakpu, HH-A Journal of U (2021) Expression of severe acute respiratory syndrome coronavirus 2 cell entry genes, angiotensin-converting enzyme 2 and transmembrane protease serine 2, in the, Elsevier (n.d.). https://www.sciencedirect. com/science/article/pii/S000293782030884X (Accessed 16 April 2021)

21. Lü M, Qiu L, Jia G, Guo R, Leng Q (2020) Single-cell expression profiles of ACE2 and TMPRSS2 reveals potential vertical transmission and fetus infection of SARS-CoV-2. Aging (Albany NY) 12:19880-19897. https://doi.org/10.18632/aging.104015

22. Komine-Aizawa S, Takada K, Hayakawa S (2020) Placental barrier against COVID-19. Placenta 99:45-49. https://doi.org/10. 1016/j.placenta.2020.07.022

23. Chen S, Huang B, Li X, Yang F, Zhao Y, Nie X, Huang B (2020) Pregnancy with new coronavirus infection: clinical characteristics and placental pathological analysis of three cases. Chin J Pathol 49:291-293

24. Yu N, Li W, Kang Q, Xiong Z, Wang S, Lin X, Liu Y, Xiao J, Liu H, Deng D, Chen S, Zeng W, Feng L, Wu J (2020) Clinical features and obstetric and neonatal outcomes of pregnant patients with COVID-19 in Wuhan, China: a retrospective, single-centre, descriptive study. Lancet Infect Dis 20:559-564. https://doi.org/ 10.1016/S1473-3099(20)30176-6

25. Wang S, Guo L, Chen L, Liu W, Cao Y, Zhang J, Feng L (2020) A case report of neonatal 2019 coronavirus disease in China. Clin Infect Dis 71:853-857. https://doi.org/10.1093/cid/ciaa225

26. Mimouni F, Lakshminrusimha S, Pearlman SA, Raju T, Gallagher PG, Mendlovic J (2020) Perinatal aspects on the covid-19 pandemic: a practical resource for perinatal-neonatal specialists. J Perinatol 40:820-826. https://doi.org/10.1038/s41372-020-0665-6

27. Schwartz DA (2020) An analysis of 38 pregnant women with COVID-19, their newborn infants, and maternal-fetal transmission of SARS-CoV-2: maternal coronavirus infections and pregnancy outcomes. Arch Pathol Lab Med 144:799-805. https://doi.org/10. 5858/arpa.2020-0901-SA

28. A Vivanti, C Vauloup-Fellous, S.P-Communications U (2020) Transplacental transmission of SARS-CoV-2 infection, NatureCom (n.d.). https://www.nature.com/articles/s41467-02017436-6?fbclid=IwAR1qnSTI_bHXm3x4GGTI25snwtoZxivAv9 GzGqj3YOARnJEMoBs5rIKOjys (Accessed 16 April 2021)

29. Ferraiolo A, Barra F, Kratochwila C, Paudice M, Vellone VG, Godano E, Varesano S, Noberasco G, Ferrero S, Arioni C (2020) 
Report of positive placental swabs for sars-cov-2 in an asymptomatic pregnant woman with covid-19. Medicina 56:1-9. https:// doi.org/10.3390/medicina56060306

30. Hosier H, Farhadian S, Morotti RA, Deshmukh U, Lu-Culligan A, Campbell KH, Yasumoto Y, Vogels CBF, Casanovas-Massana A, Vijayakumar P, Geng B, Odio CD, Fournier J, Brito AF, Fauver JR, Liu F, Alpert T, Tal R, Szigeti-Buck K, Perincheri S, Larsen C, Gariepy AM, Aguilar G, Fardelmann KL, Harigopal M, Taylor HS, Pettker CM, Wyllie AL, Dela Cruz C, Ring AM, Grubaugh ND, Ko AI, Horvath TL, Iwasaki A, Reddy UM, Lipkind HS (2020) SARS-CoV-2 infection of the placenta. MedRxiv. https:// doi.org/10.1101/2020.04.30.20083907

31. Algarroba GN, Hanna NN, Rekawek P, Vahanian SA, Khullar P, Palaia T, Peltier MR, Chavez MR, Vintzileos AM (2020) Confirmatory evidence of the visualization of severe acute respiratory syndrome coronavirus 2 invading the human placenta using electron microscopy. Am J Obstet Gynecol 223:953-954. https:// doi.org/10.1016/j.ajog.2020.08.106

32. Mongula JE, Frenken MWE, van Lijnschoten G, Arents NLA, de Wit-Zuurendonk LD, Schimmel-de Kok APA, van Runnard Heimel PJ, Porath MM, Goossens SMTA (2020) COVID-19 during pregnancy: non-reassuring fetal heart rate, placental pathology and coagulopathy. Ultrasound Obstet Gynecol 56:773-776. https://doi.org/10.1002/uog.22189

33. Lokken EM, Walker CL, Delaney S, Kachikis A, Kretzer NM, Erickson A, Resnick R, Vanderhoeven J, Hwang JK, Barnhart N, Rah J, McCartney SA, Ma KK, Huebner EM, Thomas C, Sheng JS, Paek BW, Retzlaff K, Kline CR, Munson J, Blain M, LaCourse SM, Deutsch G, Adams Waldorf KM (2020) Clinical characteristics of 46 pregnant women with a severe acute respiratory syndrome coronavirus 2 infection in Washington State. Am J Obstet Gynecol 223:911.e1-911.e14. https://doi.org/10.1016/j.ajog.2020. 05.031

34. Richtmann R, Torloni MR, Oyamada Otani AR, Levi JE, Crema Tobara M, de Almeida Silva C, Dias L, Miglioli-Galvão L, Martins Silva P, Macoto Kondo M (2020) Fetal deaths in pregnancies with SARS-CoV-2 infection in Brazil: a case series. Case Rep Women's Heal. https://doi.org/10.1016/j.crwh.2020.e00243

35. Wong YP, Khong TY, Tan GC (2021) The effects of COVID-19 on placenta and pregnancy: what do we know so far? Diagnostics 11:94. https://doi.org/10.3390/diagnostics11010094

36. Pique-Regi R, Romero R, Tarca AL, Luca F, Xu Y, Alazizi A, Leng Y, Hsu CD, Gomez-Lopez N (2020) Does the human placenta express the canonical cell entry mediators for SARS-CoV-2? BioRxiv. https://doi.org/10.1101/2020.05.18.101485

37. MA Ashraf, P Keshavarz, P Hosseinpour, A Erfani, A Roshanshad, A Pourdast, P Nowrouzi-Sohrabi, S Chaichian, T Poordast (2020) Coronavirus disease 2019 (COVID-19): a systematic review of pregnancy and the possibility of vertical transmission, J Reprod Infertil, 21: 157-168. https://www.ncbi.nlm.nih.gov/ pmc/articles/pmc7362089/ (Accessed 16 April 2021)

38. Kayem G, Lecarpentier E, Deruelle P, Bretelle F, Azria E, Blanc J, Bohec C, Bornes M, Ceccaldi PF, Chalet Y, Chauleur C, Cordier AG, Desbrière R, Doret M, Dreyfus M, Driessen M, Fermaut M, Gallot D, Garabédian C, Huissoud C, Luton D, Morel O, Perrotin F, Picone O, Rozenberg P, Sentilhes L, Sroussi J, Vayssière C, Verspyck E, Vivanti AJ, Winer N, Alessandrini V, Schmitz T (2020) A snapshot of the COVID-19 pandemic among pregnant women in France. J Gynecol Obstet Hum Reprod 49:101826. https://doi.org/10.1016/j.jogoh.2020.101826

39. Smith V, Seo D, Warty R, Payne O, Salih M, Chin KL, OforiAsenso R, Krishnan S, Da Silva Costa F, Vollenhoven B, Wallace E (2020) Maternal and neonatal outcomes associated with COVID-19 infection: a systematic review. PLoS ONE. https://doi. org/10.1371/journal.pone.0234187

Publisher's Note Springer Nature remains neutral with regard to jurisdictional claims in published maps and institutional affiliations. 